\title{
Analiza dotychczasowych prób lokalizacji elektroenergetycznej linii przesyłowej 400 kV Kozienice-Ołtarzew
}

\section{Zbigniew Cieszkowski}

\begin{abstract}
STRESZCZENIE
Celem niniejszego artykułu jest przedstawienie uwarunkowań i dotychczasowych działań na rzecz ustalenia lokalizacji przesyłowej linii elektroenergetycznej najwyższych napięć 400 kV Kozienice-Ołtarzew, stanowiącej istotny element warszawskiego pierścienia elektroenergetycznego i przyczyniającej się do zwiększenia niezawodności zaopatrzenia w energię elektryczną aglomeracji warszawskiej i znacznej części Mazowsza. Za zapewnienie bezpieczeństwa funkcjonowania przesyłowego systemu elektroenergetycznego odpowiadają Polskie Sieci Elektroenergetyczne S.A. (PSE S.A.), będące operatorem tego systemu na obszarze Rzeczypospolitej Polskiej. W związku z tym, że zapotrzebowanie na energię elektryczną w województwie mazowieckim, a w szczególności w aglomeracji warszawskiej stale rośnie, niezbędny jest rozwój krajowej sieci przesyłowej. Artykuł prezentuje historyczne plany rozbudowy systemu przesyłowego, zasilającego Warszawę oraz podjęte działania zmierzające do wprowadzenia planowanej linii 400 kV Kozienice-Ołtarzew do dokumentów planistycznych gmin, które w 2015 r. zapoczątkowały protesty społeczne przeciwko tej inwestycji. Mieszkańcy, grupy społeczne oraz samorządy lokalne wyrażali swoje niezadowolenie w pismach kierowanych m.in. do inwestora - PSE S.A., organów administracji rządowej jak również samorządu Województwa Mazowieckiego. Władze samorządowe regionu nie pozostały obojętne na protesty społeczne, dlatego włączyły się w dialog w roli mediatora pomiędzy stroną rządową a samorządowo-społeczną. We wrześniu 2015 r. z inicjatywy Sejmiku Województwa Mazowieckiego powstało Forum Dialogu, w którego obradach brali udział przedstawiciele: inwestora, administracji rządowej i władz gminnych oraz lokalnej społeczności. Zadaniem Forum było wypracowanie nowego, kompromisowego przebiegu linii 400 kV Kozienice-Ołtarzew, który mógłby być uwzględniony w zmienionym Planie Zagospodarowania Przestrzennego Województwa Mazowieckiego. W artykule przedstawiono analizowane warianty oraz sposób wyboru optymalnej trasy linii, która ostatecznie nie została procedowana ze względu na dużą skalę protestów społecznych. Na początku 2017 r. PSE S.A. przyjęło nowy model realizacji inwestycji i przystąpiło do prac analitycznych, mających na celu ustalenie trasy przedmiotowej linii. Inwestor planuje publicznie zaprezentować wyniki tych prac w połowie 2018 r. i poddać je konsultacjom publicznym.
\end{abstract}

\section{Historia warszawskiego pierścienia linii elektroenergetycznych 400 kV i 220 kV}

Historia budowy i rozbudowy elektroenergetycznych sieci przesyłowych najwyższych napięć 220 kV i 400 kV, służących zasilaniu Warszawy i centralnych obszarów ówczesnego województwa warszawskiego sięga swoim początkiem pierwszej połowy lat 50 . ubiegłego wieku. Intensywny rozwój kraju po zniszczeniach wojennych, w tym rozwój energochłonnych gałęzi przemysłu i powszechna elektryfikacja, spowodowały bardzo duży wzrost zapotrzebowania na energię elektryczną, któremu nie mogły już sprostać przestarzałe sieci wysokiego napięcia $110 \mathrm{kV}$ dostarczające energię do Łodzi i Warszawy z elektrowni zlokalizowanych na Górnym Śląsku. Opracowana na początku lat 50. koncepcja rozwoju krajowego systemu elektroenergetycznego zakładała budowę bardzo nowoczesnego, jak 
na owe czasy, systemu sieci przesyłowych 220 kV oraz dużych źródeł energii elektrycznej lub elektrycznej i cieplnej. Pierwszymi elementami przesyłowych sieci $220 \mathrm{kV}$ dla zasilania Warszawy i okolic była wybudowana w 1954 r. stacja 220/110 kV Mory i linia 220 kV Radom-Mory. W 1955 r. powstała linia 220 kV Łódź-Mory, co zamknęło pierścień zasilający Warszawę z Górnego Śląska, z jednej strony przez Łódź, z drugiej przez Radom. Dwustronny przesył energii na napięciu $220 \mathrm{kV}$ wyraźnie poprawił parametry zasilania Warszawy, która pomimo uruchomienia w 1954 r. Elektrociepłowni (EC) Żerań była w dalszym ciągu w stanie wyraźnego deficytu energetycznego. Następnymi elementami sieci przesyłowych i systemu wytwarzania energii elektrycznej, mającymi istotny wpływ na zasilanie Warszawy i ówczesnego województwa warszawskiego były wybudowane w latach:

1959 r. linia 220 kV elektrownia Konin-Mory,

1960 r. Elektrociepłownia Siekierki,

1966 r. stacja 220/110 kV Miłosna,

1966 r. linia 220 kV Mory-Miłosna,

1967 r. linia 220 kV elektrownia Pątnów-Mory,

1968-1979 elektrownia Kozienice,

1971 r. linia 220 kV elektrownia Kozienice-Miłosna,

1972 r. linia 220 kV elektrownia Ostrołęa-Miłosna,

1973 r. linia 220 kV Mory-Warszawa Towarowa,

1973 r. stacja 220/110 kV Warszawa Towarowa.

Według stanu z połowy lat 70., Warszawa była już zasilana wielokierunkowo systemem sieci 220 kV z kilku źródeł: elektrowni Kozienice, elektrowni śląskich, zespołu elektrowni Pątnów-Adamów-Konin, elektrowni Ostrołęka.

Drugi etap rozwoju systemu przesyłowych sieci elektroenergetycznych zasilających Warszawski Węzeł Elektroenergetyczny zapoczątkowany został w 1977 r. sporządzeniem przez Biuro Projektów Rozwoju Warszawy (BPRW) Koncepcji generalnej rozwoju systemu elektroenergetycznego dla województwa stołecznego warszawskiego (województwa utworzonego w 1975 r. w wyniku reformy administracyjnej kraju). Koncepcja zakładała rozbudowę systemu przesyłowego $220 \mathrm{kV}$ oraz budowę sieci nowego napięcia $400 \mathrm{kV}$, w tym:

- budowę warszawskiego pierścienia $400 \mathrm{kV}$, czyli dwutorowej linii relacji: OłtarzewMościska-Miłosna-Julianów-Piaseczno-Ołtarzew (oznaczonej kolorem niebieskim na mapie 1- na tle stanu z 2017 r., wg którego część projektowanych linii i stacji już istnieje),

- budowę linii $400 \mathrm{kV}$ Bełchatów-Ołtarzew (alternatywnie Koniecpol-Ołtarzew w przypadku budowy elektrowni Koniecpol zamiast elektrowni Bełchatów),

- budowę linii 400 kV: Kozienice-Miłosna, Miłosna-Białystok, Miłosna-Siedlce,

- budowę węzłowej stacji 400/220/110 kV Ołtarzew,

- przebudowę stacji 220/110 kV Miłosna i Mory na węzłowe stacje 400/220/110 kV,

- budowę stacji: 400/220/110 kV Piaseczno, 400/110 kV: Mościska, Huta Warszawa, Julianów, EC Mańki,

- budowę 2 nowych źródeł energii elektrycznej i cieplnej, czyli EC Mańki (gm. Nieporęt) i EC Kawęczyn w Warszawie. 


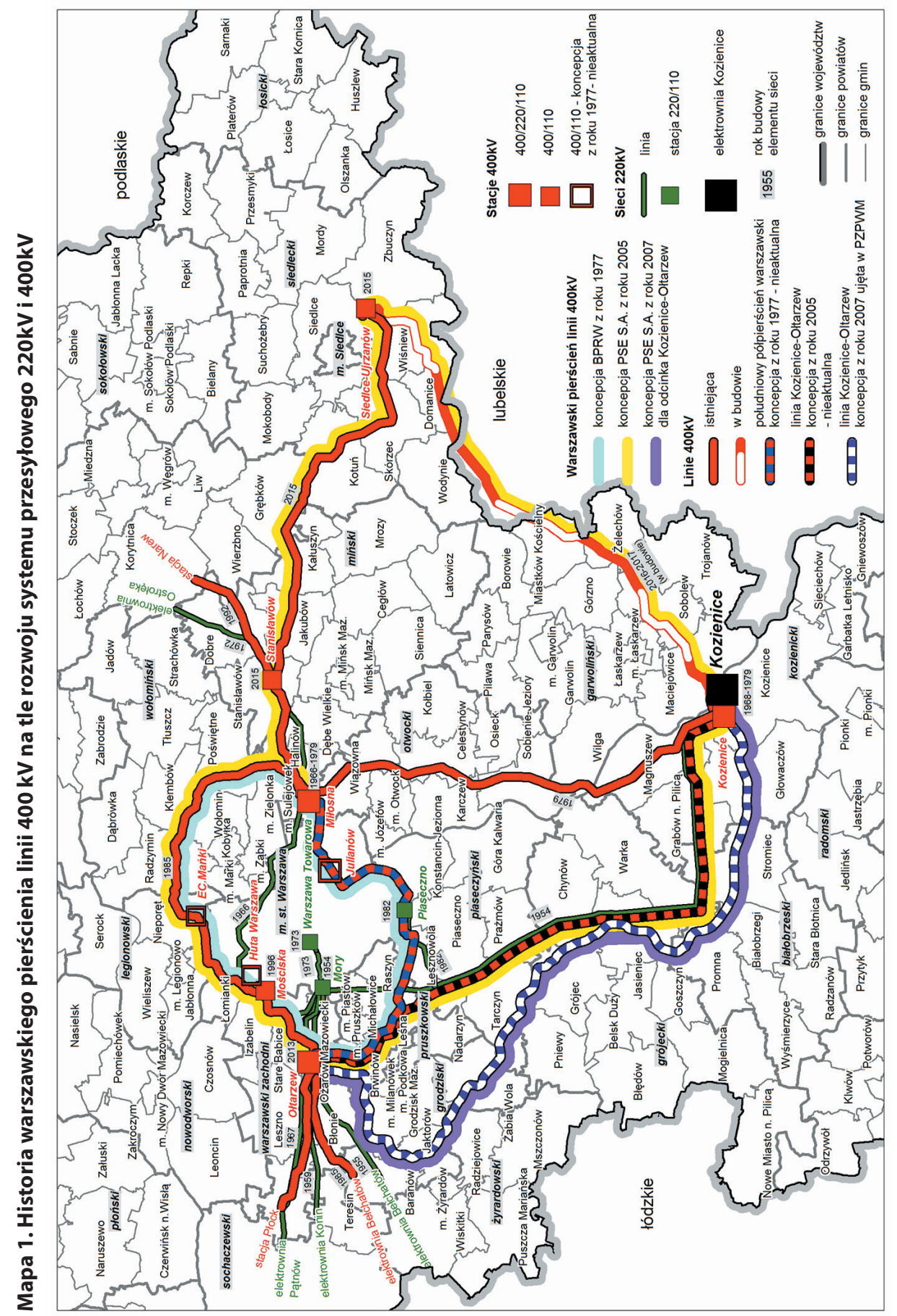


Realizacja sieci objętych koncepcją rozpoczęła się w 1979 r. budową linii 400 kV z elektrowni Kozienice do stacji Miłosna, którą równocześnie rozbudowano do poziomu 400 kV, co zdecydowanie zwiększyło możliwość przesyłu energii do Warszawy. W 1983 r. wybudowano stację 220/110 kV Piaseczno i wpięto ją w istniejącą linię 220 kV Kozienice-Mory z zamiarem późniejszego przyłączenia stacji w Piasecznie do planowanego południowego pierścienia warszawskiego $400 \mathrm{kV}$ Miłosna-Piaseczno-Ołtarzew.

Następnym milowym krokiem w rozwoju systemu przesyłowego $400 \mathrm{kV}$ było uruchomienie w 1985 r. strategicznego ciągu liniowego: elektrownia Bełchatów (stacja Rogowiec)-Miłosna (z odgałęzieniem do Płocka), w ramach którego powstał północny półpierścień warszawski, a Warszawski Węzeł Elektroenergetyczny (WWE) otrzymał energię z wybudowanej w latach 1981-1988 i sukcesywnie uruchamianej elektrowni Bełchatów. Linia z Bełchatowa do terenu planowanej stacji 400/220/110 kV Ołtarzew wybudowana została na trasie innej niż zakładała koncepcja BPRW z 1977 r. W latach 80. całkowicie zrezygnowano z budowy elektrociepłowni Mańki, budowy członu elektroenergetycznego w ciepłowni Kawęczyn, budowy stacji 400/110 kV Huta Warszawa. W 1992 r. zakończono budowę i uruchomiono linię 400 kV Miłosna-Białystok (stacja 400/110 kV Narew), w 1996 r. stację 400/110 kV Mościska, którą wpięto w linię 400 kV Bełchatów-Miłosna (czyli w północny pierścień warszawski). Otwarty pozostał plan budowy południowego półpierścienia $400 \mathrm{kV}$ Miłosna-Piaseczno-Ołtarzew wraz z budową stacji węzłowej 400/220/110 kV Ołtarzew, stacji 400/110 kV Julianów i rozbudową do poziomu 400 kV stacji 220/110 kV Piaseczno. Trasa tego półpierścienia w koncepcji BPRW z 1977 r. wiodła przez gminy: Sulejówek, Wiązowna, m.st. Warszawa, Konstancin-Jeziorna, Piaseczno, Lesznowola, Raszyn, Nadarzyn, Brwinów, Ożarów Mazowiecki.

Przemiany polityczne, gospodarcze i społeczne, jakie zaszły w Polsce po 1989 r. wywarły bardzo duży wpływ na sektor energetyczny. Likwidacja energochłonnych gałęzi przemysłu spowodowała spadek zapotrzebowania na energię elektryczna, a to z kolei spowolniło tempo budowy i rozbudowy systemu elektroenergetycznego. Istotne znaczenie miało również zreorganizowanie systemu zarządzania przedsiębiorstwami energetycznymi, zostały one przekształcone z centralnie zarządzanych przedsiębiorstw użyteczności publicznej w spółki Skarbu Państwa, działające na zasadzie przedsiębiorstw komercyjnych. Zarządzanie przesyłowymi sieciami elektroenergetycznymi najwyższych napięć $400 \mathrm{kV}$ i $220 \mathrm{kV}$ przejęła jednoosobowa spółka Skarbu Państwa Polskie Sieci Elektroenergetyczne S.A. (PSE S.A.). Lata 1996-2004 to okres stagnacji w rozwoju systemu przesyłowego, nie tylko w województwie mazowieckim, ale też na terenie całego kraju. Brak w tamtym czasie realnego zainteresowania PSE S.A. budową południowego półpierścienia warszawskiego $400 \mathrm{kV}$, zaowocował szybkim zabudowaniem korytarza przeznaczonego na ten cel w planach miejscowych, które utraciły moc wskutek zmian prawnych. Brak aktualnej trasy tego ciągu był przyczyną nieujęcia go w formie graficznej w ówczesnym Planie Zagospodarowania Przestrzennego Województwa Mazowieckiego (uchwalonym w 2004 r.), a jedynie w formie ogólnego zapisu. 
Trzeci etap prac nad rozbudową elektroenergetycznych sieci przesyłowych $400 \mathrm{kV}$ w obszarze Warszawskiego Węzła Elektroenergetycznego rozpoczął się w 2004 r., w wyniku decyzji politycznych wynikających z przystąpienia Polski do Unii Europejskiej, dotyczących integracji europejskich elektroenergetycznych sieci przesyłowych. W ramach prac analitycznych, w 2005 r. opracowano nową koncepcję pierścienia warszawskiego $400 \mathrm{kV}$, do którego bezpośrednio włączona byłaby elektrownia Kozienice. Południowo-zachodnią część tego ciągu miała tworzyć linia Kozienice-Ołtarzew, planowana w większości po trasie istniejącej linii $220 \mathrm{kV}$ Kozienice-Mory (ten wariant linii Kozienice-Ołtarzew w późniejszych analizach zyskał miano „historycznego”). Południowo-wschodnia część pierścienia oparta była na trasie istniejącej linii $220 \mathrm{kV}$ Kozienice-Siedlce Ujrzanów, planowanej do przebudowy na $400 \mathrm{kV}$ oraz na nowej linii 400 kV Miłosna-StanisławówSiedlce Ujrzanów. Ideę całego pierścienia warszawskiego z 2005 r. wyróżniono kolorem żółtym na mapie 1.

W latach 2005-2007, kiedy m.in. w związku z planowanym mostem energetycznym Polska-Litwa powstała koncepcja budowy sieci przesyłowych $400 \mathrm{kV}$ w północnowschodnim i centralnym obszarze kraju, a elektrownia Kozienice została objęta programem rozbudowy polskiego systemu wytwarzania energii elektrycznej (zaplanowano budowę nowoczesnego bloku energetycznego o mocy 1075 MW) ww. idea uległa częściowej modyfikacji. Przeprowadzone w tym czasie wszechstronne analizy techniczne i przestrzenne wykazały, że konieczna będzie budowa całkowicie nowej dwutorowej linii 400 kV KozieniceOłtarzew. Głównymi przyczynami rezygnacji z przebudowy linii 220 kV KozienicePiaseczno-Mory na linię 400 kV były: brak możliwości wyłączenia linii 220 kV z eksploatacji na czas przebudowy, wynikający ze wzrostu zapotrzebowania aglomeracji warszawskiej na energię elektryczną oraz brak możliwości zapewnienia wystarczających dostaw energii trasami alternatywnymi, wysoki stopień urbanizacji terenów wokół korytarza linii $220 \mathrm{kV}$ w gminach podwarszawskich, co w przypadku przebudowy na linię $400 \mathrm{kV}$ wymagałoby wyburzeń wielu budynków mieszkalnych.

Wypracowana w 2007 r. idea rozbudowy sytemu przesyłowego w okolicach Warszawy znalazła się w Planie rozwoju w zakresie zaspokojenia obecnego i przyszłego zapotrzebowania na energię elektryczna na lata 2010-2025, przyjętym przez PSE S.A. w 2009 r., a w 2011 r. została ujęta w Koncepcji Przestrzennego Zagospodarowania Kraju 2030 (KPZK).Tym samym inwestycje służące realizacji przedmiotowej idei uzyskały podstawę prawną do ich uwzględnienia w ówcześnie aktualizowanym Planie Zagospodarowania Przestrzennego Województwa Mazowieckiego (PZPWM), uchwalonym w 2014 r.

Od tego czasu zrealizowano: stację 400/220/110 kV Ołtarzew, stację 400/110 kV Stanisławów, stację 400/110 kV Siedlce Ujrzanów oraz linię 400 kV Miłosna-StanisławówSiedlce Ujrzanów. W 2016 r. rozpoczęto budowę linii 400 kV Kozienice-Siedlce Ujrzanów. Olbrzymie problemy pojawiły się natomiast przed PSE S.A. przy ustalaniu lokalizacji linii Kozienice-Ołtarzew, gdyż próby wprowadzenia tej linii do dokumentów planistycznych gmin spotkały się ze zdecydowanymi protestami społecznymi. Zamiar 
budowy nowej, dwutorowej napowietrznej linii $400 \mathrm{kV}$, przebiegającej przez intensywnie zurbanizowane tereny podwarszawskie, wzbudził ogromne obawy, ponieważ przedmiotowa inwestycja należy do grupy obiektów zawsze i istotnie oddziaływających na środowisko:

- jest źródłem promieniowania elektromagnetycznego o składowej elektrycznej i magnetycznej, niekorzystnie oddziaływającego na organizmy żywe - ograniczenie oddziaływania na człowieka i zwierzęta do wartości dopuszczalnej przez przepisy prawne i normy techniczne następuje poprzez odpowiednio wysokie zawieszenie przewodów linii oraz odpowiednie dla danego rodzaju linii i słupów wsporczych odległości ochronne mierzone od skrajnych przewodów w obydwie strony linii; odległości te odnoszone do budynków mieszkalnych i innych, w przypadku polskiego prawa jedne z najbardziej rygorystycznych w Europie, ustalane są przez zespół projektowy na etapie wyboru trasy linii w terenie i adaptacji do konkretnych warunków terenowych poszczególnych konstrukcji wsporczych (popularnie - słupów),

- jest źródłem hałasu spowodowanego tzw. ulotem, czyli rodzajem ograniczonego przebiegu w powietrzu energii elektrycznej, słyszanego jako trzask lub syk oraz hałasu powodowanego przez wiatr owiewający przy większych prędkościach elementy konstrukcyjne słupów oraz przewody - zmniejszenie tego rodzaju oddziaływania realizowane jest przez zachowanie odpowiednich odległości ochronnych od budynków przeznaczonych na pobyt ludzi na zasadach podobnych do ustalania ochrony przed promieniowaniem elektromagnetycznym,

- w stanach awaryjnych (zerwanie przewodu) przewody linii stanowią zagrożenie pożarowe dla obiektów i porażeniowe dla ludzi znajdujących się w obszarze oddziaływania danej linii - stąd również zakaz zabudowy w tym obszarze,

- w praktyce teren wzdłuż trasy linii o szerokości 2x35 m (w niektórych przypadkach 2x40 m), nazywany pasem technologicznym, wyłączony jest z wszelkiej zabudowy kubaturowej oraz podlega innym ograniczeniom wykorzystania przestrzeni, $\mathrm{w}$ tym tworzenia nasypów, składowisk materiałów, pracy wysokiego sprzętu budowlanego; bez istotnego ograniczenia dopuszczalne jest jedynie użytkowanie rolnicze z użyciem tradycyjnego sprzętu mechanicznego,

- jest elementem bardzo niekorzystnie oddziaływającym na wartość rynkową gruntów pod linią oraz w odległości nawet kilkuset metrów od niej, zakres i skala tego oddziaływania jest największa na terenach budowlanych lub potencjalnie budowlanych, zwłaszcza w gminach o dużym ruchu budowlanym,

- jest elementem bardzo niekorzystnie oddziaływającym na krajobraz - konstrukcje słupów o wysokościach już od około $40 \mathrm{~m}$ do ponad $100 \mathrm{~m}$ są istotnymi dominantami krajobrazowymi, porównywalnymi z wysokoparametrowymi elektrowniami wiatrowymi,

- jest elementem niekorzystnie oddziaływającym na systemy ekologiczne, obszary chronione, cenne przyrodniczo, w tym obszary NATURA 2000, 
- jest obiektem budowlanym, powodującym na etapie budowy pewne zniszczenia w uprawach rolniczych i sadowniczych, wymagającym niekiedy wyburzeń obiektów budowlanych, przebudowy innych elementów infrastruktury technicznej i komunikacyjnej.

\section{Próby wprowadzenia linii 400 kV Kozienice-Ołtarzew do dokumentów planistycznych gmin}

Pierwsze prace, zmierzające do ujęcia nowej linii $400 \mathrm{kV}$ Kozienice-Ołtarzew w dokumentach planistycznych gmin, podjęło Biuro Studiów i Projektów Energoprojekt Kraków S.A., które na zlecenie PSE S.A. (inwestora) opracowało w 2007 r. studium wykonalności tej linii. Wystąpiono wówczas do władz gmin z prośbą o zajęcie stanowiska w sprawie planowanej trasy. W odpowiedzi jedynie 2 gminy (Tarczyn, Radziejowice) negatywnie odniosły się do przedstawionej propozycji, 1 gmina (Jaktorów) nie wyraziła jednoznacznej opinii, natomiast pozostałe 13 gmin wstępnie zaakceptowało trasę, uzależniając ostateczne stanowisko od dalszych analiz i konsultacji. W efekcie ówczesnych działań inwestora, przedmiotowa linia została uwzględniona w studiach uwarunkowań i kierunków zagospodarowania przestrzennego jedynie 3 gmin (w całości w gminach: Ożarów Mazowiecki i Chynów oraz częściowo w gminie Grodzisk Mazowiecki - bez fragmentu w południowym rejonie gminy). Wprowadzenie do miejscowych planów zagospodarowania przestrzennego zostało zrealizowane tylko w gminie Ożarów Mazowiecki (najbardziej społecznie przygotowanej na tę inwestycję, gdyż na jej terenie już od 1977 r. planowano realizację stacji 400/220/110 kV Ołtarzew, a planowana linia przebiegała w tej gminie po śladzie pierwszego „historycznego” wariantu) oraz w niewielkiej części gminy Grodzisk Mazowiecki.

Druga, tym razem całkowicie nieudana, faza procesu wprowadzania linii $400 \mathrm{kV}$ Kozienice-Ołtarzew do gminnych dokumentów planistycznych na wniosek inwestora została rozpoczęta w 2014 r. - po uchwaleniu Planu Zagospodarowania Przestrzennego Województwa Mazowieckiego, w którym linia ta została uwzględniona w lokalizacji orientacyjnej, wymagającej uściślenia na etapie planowania miejscowego. Należy podkreślić, że w trakcie prowadzonej przez samorząd województwa procedury przyjmowania wniosków do Planu i opiniowania projektu dokumentu, nie wpłynęły żadne wnioski z propozycjami innej trasy ani protesty przeciwko przedmiotowej inwestycji (z wyjątkiem gminy Grodzisk Mazowiecki, która zgłosiła sprzeciw wobec niewielkiego fragmentu linii w południowej części gminy).

Planowane przyszłe prace nad aktualizacją dokumentów gminnych lub sporządzaniem nowych, poprzedzone zostały cyklem spotkań informacyjnych, zorganizowanych przez Agencję Promocji Inwestycji Sp. z o.o. (API), działającej na rzecz wykonawcy linii KozieniceOłtarzew. Spotkania z władzami gmin leżących na trasie planowanej inwestycji odbyły się w okresie od lipca do października 2014 r. i przebiegały w rzeczowej atmosferze wspólnej 
dyskusji nad szczegółami trasy, podczas których dokonywano korekt przebiegu linii w celu minimalizacji potencjalnego ryzyka wystąpienia lokalnych konfliktów środowiskowych i społecznych. Na tym etapie prac władze gmin nie sygnalizowały możliwości wystąpienia powszechnego sprzeciwu społecznego przeciwko budowie linii 400 kV Kozienice-Ołtarzew.

Przełomowym w zmianie stosunku mieszkańców oraz władz samorządowych gmin wobec inwestycji okazał się okres od kwietnia do lipca 2015 r., kiedy wskutek szczegółowych informacji, przekazanych przez API społecznościom i samorządom lokalnym, wystąpiło nienotowane wcześniej zjawisko organizowania się tych społeczności w celu wyrażania protestu przeciwko inwestycji. W okresie tym okazało się wyraźnie, że na wcześniejszych etapach prac nad wyborem optymalnej trasy linii Kozienice-Ołtarzew, zabrakło konsultacji społecznych na styku władze gminne - mieszkańcy gminy. Zarzut o braku akcji informacyjnej był wielokrotnie podnoszony w pismach protestacyjnych. Wielu mieszkańców gmin leżących na trasie projektowanej linii dowiedziało się o inwestycji oraz o jej aspekcie przestrzennym i środowiskowym dopiero w kwietniu 2015 r. podczas bezpośrednich spotkań z przedstawicielami inwestora i wykonawcy projektu. Odzwierciedleniem przekonania części społeczności lokalnych o braku dialogu społecznego, a także braku informacji o okolicznościach wprowadzenia linii do PZPWM oraz o oddziaływaniu inwestycji na środowisko, były wystąpienia organizacji społecznych, samorządów lokalnych, mediów i osób prywatnych kierowane do: Marszałka Województwa Mazowieckiego (WM), Sejmiku WM, Wojewody Mazowieckiego, Ministerstwa Infrastruktury i Rozwoju, Ministerstwa Energii, PSE S.A. Od 7 kwietnia do 8 lipca 2015 r. samorząd Województwa Mazowieckiego otrzymał łącznie 42 różnego rodzaju pisma (kierowane bezpośrednio lub przekazywane do wiadomości), z których większość dotyczyła merytorycznie więcej niż jednej gminy. Przedmiotowe pisma zawierały kilka rodzajów wystąpień:

- protesty przeciwko trasie linii uwzględnionej w PZPWM,

- prośby o udzielenie informacji w zakresie: procedury wprowadzenia linii do planu województwa, konsultacji społecznych oraz stanowisk rad gmin w procesie opiniowania projektu planu,

- różnego rodzaju informacje i propozycje zmiany trasy,

- wezwania do usunięcia naruszeń prawa, skargi do Wojewódzkiego Sądu Administracyjnego (WSA).

W świetle analizy ww. korespondencji najbardziej kontrowersyjnym okazał się odcinek linii $400 \mathrm{kV}$ Kozienice-Ołtarzew przebiegający przez południową część gminy Grodzisk Mazowiecki. Rozpoczęty w tej gminie protest przeciwko inwestycji „rozlał się” na 6 sąsiednich gmin: Jaktorów, Żabia Wola, Radziejowice, Baranowo, Tarczyn i Błonie. Należy zwrócić uwagę, że na tym etapie próby ustalenia lokalizacji przedmiotowej linii w przebiegu ujętym w PZPWM, nie wpływały pisma od mieszkańców i władz pozostałych 9 gmin znajdujących się na trasie linii.

Protest przeciwko linii $400 \mathrm{kV}$ Kozienice-Ołtarzew stał się w okresie od kwietnia do lipca 2015 r. bardzo głośnym medialnie wydarzeniem społecznym w skali województwa mazowieckiego. Skala sprzeciwu zaskoczyła wszystkich, w tym przede wszystkim PSE S.A. 
- inwestora linii. Wystąpienia skierowane do władz samorządowych regionu spowodowały ich włączenie się w dialog. Pierwsze spotkania z przedstawicielami protestujących odbyły się w dniach 1 i 6 lipca z udziałem radnych Sejmiku Województwa Mazowieckiego z Komisji Strategii Rozwoju Regionalnego i Zagospodarowania Przestrzennego oraz z Komisji Rozwoju Gospodarczego, Infrastruktury i Przeciwdziałania Bezrobociu. W związku z tym, że pojawiły się propozycje nowych tras linii Kozienice-Ołtarzew (w tym wniosek skierowany przez Wójta Gminy Żabia Wola do Prezesa Zarządu PSE S.A. w sprawie poprowadzenia jej w korytarzach komunikacyjnych: drogi krajowej nr 50 i autostrady A2), następne spotkanie w dniu 20 lipca zaowocowało decyzją o rekomendowaniu Sejmikowi Województwa Mazowieckiego podjęcia prac nad zmianą PZPWM w zakresie przebiegu przedmiotowej linii. Uchwala w tej sprawie została podjęta na posiedzeniu Sejmiku w dniu 27 lipca 2015 r. Otworzyło to nowy etap dyskusji nad trasą tej konfliktowej inwestycji. Społeczeństwo otrzymało sygnał, że procedura zmiany planu zagospodarowania przestrzennego województwa umożliwi wzięcie pod uwagę innych niż dotychczas wariantów przebiegu linii 400 kV Kozienice-Ołtarzew. W tym okresie kilka gmin podjęło uchwały o przystąpieniu do aktualizacji studiów uwarunkowań i kierunków zagospodarowania przestrzennego (tabela 1, mapa 2).

\section{Poszukiwania nowej lokalizacji linii 400 kV Kozienice-Ołtarzew w latach 2015-2016}

W związku z falą protestów i propozycjami innego przebiegu planowanej linii KozieniceOłtarzew, zespół projektowy API rozpoczął prace studialne nad trasami alternatywnymi, w tym nad 2 wariantami wykorzystującymi korytarze komunikacyjne: drogi krajowej nr 50 (DK 50) i autostrady A2. Wyniki tych prac zostały upublicznione w okresie od 1 lipca do 10 sierpnia 2015 r. i także zostały oprotestowane (pierwszy sprzeciw przeciwko nowym wariantom został złożony 20 lipca 2015 r.).

We wrześniu 2015 r. z inicjatywy Sejmiku Województwa Mazowieckiego powstało Forum Dialogu, w którego obradach spotkali się na prawach stron przedstawiciele: inwestora, administracji rządowej i władz gminnych oraz strona społeczna, czyli stowarzyszenia i osoby fizyczne. Należy podkreślić, że samorząd województwa nie był w tych spotkaniach strona, lecz mediatorem pomiędzy stroną rządową a samorządowo-społeczną. Zadaniem Forum było wypracowanie nowego, kompromisowego przebiegu linii 400 kV Kozienice-Ołtarzew, który mógłby być uwzględniony w zmienionym PZPWM. Analizie poddano 5 wariantów trasy:

- wariant ujęty w PZPWM,

- wariant PSE S.A. (zmodyfikowany przebieg z PZPWM),

- wariant wzdłuż drogi krajowej nr 50 i autostrady A2,

- wariant wzdłuż drogi krajowej nr 50 i istniejącej linii 400 kV Rogowiec-Ołtarzew,

- wariant historyczny, czyli w większości wzdłuż istniejącej linii 220 kV Kozienice-Mory (analizowany mimo opinii PSE S.A., że jest on niemożliwy do realizacji ze względu na olbrzymią kolizyjność - w pasie technologicznym linii znajduje się ponad 100 budynków). 
Tabela 1. Studia uwarunkowań i kierunków zagospodarowania przestrzennego gmin na trasie linii 400 kV Kozienice-Ołtarzew uwzględnionej w PZPWM (stan na 31 maja 2017 r.)

\begin{tabular}{|c|c|c|c|c|}
\hline \multirow[b]{2}{*}{ Gmina } & \multicolumn{2}{|c|}{ Studium obowiązujące } & \multirow[b]{2}{*}{ Studium w trakcie zmian } & \multirow{2}{*}{$\begin{array}{c}\text { Ustalenia } \\
\text { w sprawie } \\
\text { linii } \\
\text { Kozienice- } \\
\text { Ołtarzew } \\
\text { z PZPWM }\end{array}$} \\
\hline & $\begin{array}{c}\text { uchwalone na podstawie } \\
\text { ustawy } \\
\text { z } 1994 \text { r.1 }\end{array}$ & $\begin{array}{c}\text { uchwalone na podstawie } \\
\text { ustawy } \\
\text { z } 2003 \text { r.2 }\end{array}$ & & \\
\hline Baranów & & $\begin{array}{l}\text { uchwała nrXXXVII/202/2006 } \\
\text { z dn. 22.06.2006 r. }\end{array}$ & & BRAK \\
\hline Białobrzegi & $\begin{array}{l}\text { uchwała nr XIII/54/99 } \\
\text { z dn. 08.06.1999 r., } \\
\text { zmiana fragmen- } \\
\text { tu (uchwała nr } \\
\text { XXVIII/216/2013 } \\
\text { z dn. 29.05.2013 r.) }\end{array}$ & & $\begin{array}{l}\text { uchwała nr XXI/178/2016 } \\
\text { Rady Miasta i Gminy } \\
\text { Białobrzegi } \\
\text { z dn. 23.08.2016 r. } \\
\text { w sprawie: zmny uchwa- } \\
\text { ły nr XXVIII/216/2013 } \\
\text { Rady Miasta i Gminy } \\
\text { Białobrzegi z dn. } \\
\text { 29.05.2013 r. w sprawie } \\
\text { przystapienia do zmiany } \\
\text { Studium }\end{array}$ & BRAK \\
\hline Brwinów & $\begin{array}{l}\text { uchwała nr 159/III } \\
\text { z dn. } 14.04 .2000 \text { r. }\end{array}$ & & & BRAK \\
\hline Chynów & & $\begin{array}{l}\text { uchwała nr XIV/75/08 } \\
\text { z dn. 29.01.2008 r., } \\
\text { zmiany fragmentów } \\
\text { (uchwała nr IV/26/11 } \\
\text { z dn. 29.03.2011 r., } \\
\text { uchwała nr XIX/139/2013 } \\
\text { z dn. 19.02.2013 r., } \\
\text { uchwała nr XXXIII/234/2014 } \\
\text { z dn. 27.09.2014 r., } \\
\text { uchwała nr IV/32/2015 } \\
\text { z dn. 21.04.2015 r.) } \\
\end{array}$ & & TAK \\
\hline Głowaczów & $\begin{array}{l}\text { uchwała nr XXIII/185/2000 } \\
\text { z dn. 28.12.2000 r., } \\
\text { zmiany fragmentów: } \\
\text { (uchwała nr IX/41/11 } \\
\text { z dn. 22.08.2011 r., } \\
\text { uchwała nr IX/42/11 z dn. } \\
\text { 22.08.2011 r., uchwała nr } \\
\text { IX/43/11 z dn. 22.08.2011 r., } \\
\text { uchwała nr IX/48/11 z dn. } \\
\text { 22.08.2011 r.) } \\
\end{array}$ & & & BRAK \\
\hline $\begin{array}{c}\text { Grodzisk } \\
\text { Mazowiecki }\end{array}$ & & $\begin{array}{l}\text { uchwała nr 337/2012 } \\
\text { z dn. 22.05.2012 r. }\end{array}$ & $\begin{array}{l}\text { uchwała nr 190/2015 } \\
\text { z dn. } 24.06 .2015 \text { r. (w celu } \\
\text { wyznaczenia przebiegu } \\
\text { linii } 400 \mathrm{kV} \text { Kozienice- } \\
\text { Ołtarzew w południowej } \\
\text { części gminy) }\end{array}$ & $\begin{array}{l}\text { częściowo } \\
\text { (zawarto tyl- } \\
\text { ko fragment } \\
\text { trasy w pół- } \\
\text { nocnej części } \\
\text { gminy) }\end{array}$ \\
\hline
\end{tabular}




\begin{tabular}{|c|c|c|c|c|}
\hline Grójec & & $\begin{array}{l}\text { uchwała } \\
\text { nr XXX/229/12 } \\
\text { z dn. } 10.09 .2012 \text { r. }\end{array}$ & & BRAK \\
\hline Jaktorów & $\begin{array}{l}\text { uchwała nr XXX/153/2001 } \\
\text { z dn. 08.06.2001 r. }\end{array}$ & & & BRAK \\
\hline Jasieniec & $\begin{array}{l}\text { uchwała nr VIII/61/99 } \\
\text { z dn. 25.10.1999 r. }\end{array}$ & & & BRAK \\
\hline Kozienice & & $\begin{array}{l}\text { uchwała } \\
\text { nr XXXIV/317/2008 } \\
\text { z dn. 09.10.2008 r. }\end{array}$ & $\begin{array}{l}\text { przystąpiono do spo- } \\
\text { rządzenia zmiany stu- } \\
\text { dium dla jednej działki } \\
\text { (uchwała nr VII/56/2015 } \\
\text { z dn. } 02.06 .2015 \text { r.) }\end{array}$ & BRAK \\
\hline $\begin{array}{c}\text { Ożarów } \\
\text { Mazowiecki }\end{array}$ & $\begin{array}{l}\text { uchwała nr } 464 / 10 \mathrm{z} \text { dn. } \\
15.06 .2010 \mathrm{r} \text {. }\end{array}$ & & $\begin{array}{l}\text { uchwała nr LII/510/14 } \\
\text { z dn. 15.05.2014 r. }\end{array}$ & TAK \\
\hline Promna & $\begin{array}{l}\text { uchwała nr II/5/2000 } \\
\text { z dn. } 31.02 .2000 \text { r., } \\
\text { zmiana fragmentów } \\
\text { (uchwała nr } \\
\text { z dn. 14.03.2012 r.) } \\
\text { uchwała nr XXIX/101/12 } \\
\text { z 14.03.2012 r.) }\end{array}$ & & & BRAK \\
\hline Radziejowice & & $\begin{array}{l}\text { uchwała nr XLII/213/2006 } \\
\text { z dn. 14.09.2006 r., } \\
\text { zmiany fragmentów } \\
\text { (uchwała nr XIII/87/2011 } \\
\text { z dn. 14.11.2011 r., } \\
\text { uchwała nr XIV/89/2011 } \\
\text { z dn. 05.12.2011 r., } \\
\text { uchwała nr XXII/158/2012 } \\
\text { z dn. 21.06.2012 r.) }\end{array}$ & $\begin{array}{l}\text { uchwała nr IV/19/2015 } \\
\text { z dn. } 12.02 .2015 \text { r. }\end{array}$ & BRAK \\
\hline Stromiec & $\begin{array}{l}\text { uchwała nr VII/55/99 z dn. } \\
\text { 29.04.1999 r. }\end{array}$ & & & BRAK \\
\hline Tarczyn & & $\begin{array}{l}\text { uchwała nr XXXIV/200/12 } \\
\text { z dn. 28.11.2012 r. }\end{array}$ & $\begin{array}{l}\text { przystąpiono do sporzą- } \\
\text { dzenia zmiany studium } \\
\text { dla małych obszarów } \\
\text { (uchwała nr XIX/140/16 } \\
\text { z dn. 22.01.2016 r., } \\
\text { uchwała nr XXI/151/16 } \\
\text { z dn. 11.03.2016 r., } \\
\text { uchwała nr XXVII/210/16 } \\
\text { z dn. 02.09.2016 r.) }\end{array}$ & BRAK \\
\hline Żabia Wola & & $\begin{array}{l}\text { uchwała nr 8/XVII/2012 } \\
\text { z dn. } 24.04 .2012 \text { r. }\end{array}$ & & BRAK \\
\hline
\end{tabular}

Źródło: opracowanie własne MBPR

\footnotetext{
${ }^{1}$ Ustawa z dnia 7 lipca 1994 r. o zagospodarowaniu przestrzennym

${ }^{2}$ Ustawa z dnia 27 marca 2003 r. o planowaniu i zagospodarowaniu przestrzennym
} 
94 | ANALIZA DOTYCHCZASOWYCH PRÓB LOKALIZACJI ELEKTROENERGETYCZNEJ LINII PRZESYŁOWEJ 400 kV... Zbigniew Cieszkowski

Mapa 2. Studia uwarunkowań i kierunków zagospodarowania przestrzennego gmin na trasie linii 400 kV Kozienice-Ołtarzew uwzględnionej w PZPWM (stan na 31 maja 2017 r.)

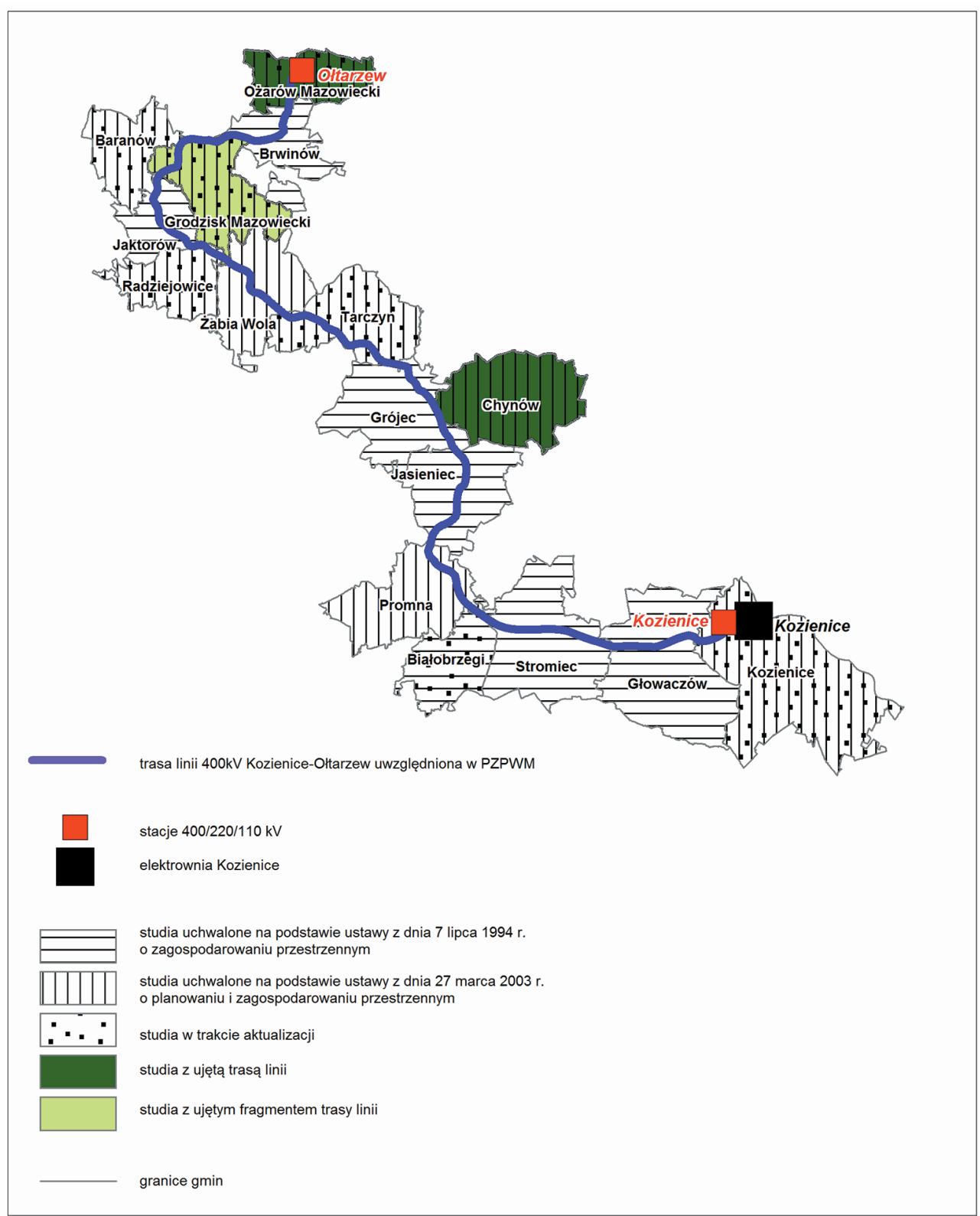

Źródło: opracowanie własne MBPR 
Trzy spotkania uczestników Forum Dialogu, odbyte w dniach: 3 i 17 września 2015 r. oraz 18 lutego 2016 r., wbrew nadziejom organizatorów nie przyniosły oczekiwanych efektów - nie doprowadziły nawet do uzgodnienia listy kryteriów służących obiektywnej ocenie dyskutowanych wariantów. Nastąpiła dalsza eskalacja konfliktu, który wyszedł poza salę obrad. Zantagonizowane grupy mieszkańców poszczególnych gmin, lokalne stowarzyszenia, komitety, przy udziale władz gminnych organizowały marsze protestacyjne. Skala konfliktu oraz agresywne wręcz zachowania części uczestników Forum wykluczyły uzyskanie konsensusu, wobec czego Forum Dialogu zostało 18 lutego 2016 r. rozwiązane.

Następną próbę wyboru akceptowalnego społecznie wariantu trasy podjęła strona rządowa, organizując Grupę Robocza, w skład której powołano inwestora i wykonawcę linii 400 kV Kozienice-Ołtarzew, wójtów, burmistrzów i prezydentów gmin leżących na trasach wszystkich wariantów linii oraz przedstawicieli organizacji społecznych. W spotkaniach Grupy Roboczej brał także udział obserwator ze strony samorządu WM. Trzy zamknięte posiedzenia Grupy odbyły się: 22 marca, 6 kwietnia i 16 maja 2016 r. Podczas ostatniego z nich przedstawiono wyniki wielokryterialnej, punktowej analizy wariantów trasy. Optymalnym w świetle przyjętych kryteriów okazał się wariant wzdłuż drogi krajowej nr 50 i autostrady A2. Wynik ten spowodował dalszą radykalizację nastrojów władz i mieszkańców gmin związanych ze wskazaną trasą. Sprawa braku porozumienia oraz nabrzmiałego konfliktu pomiędzy inwestorem a władzami i społecznościami gmin, leżących na trasach poszczególnych wariantów linii, urosła medialnie do rangi problemu wykraczającego poza region - gminy tworzyły strony internetowe związane z protestami, blokowane były drogi krajowe, o czym informowały media o zasięgu ogólnokrajowym.

W międzyczasie, do końca 2015 r., nastąpiły rozstrzygnięcia w sprawie skarg na zapisy obowiązującego Planu Zagospodarowania Przestrzennego Województwa Mazowieckiego, kierowanych w poprzednich miesiącach do Wojewódzkiego Sądu Administracyjnego i Naczelnego Sądu Administracyjnego przez właścicieli nieruchomości, organizacje społeczne i władze gmin. Należy podkreślić, że sądy uznały wszystkie skargi za bezzasadne, a więc PZPWM pozostał w mocy.

Dnia 2 sierpnia 2016 r. na stronie internetowej PSE S.A. została opublikowana nieoczekiwana decyzja strony rządowej o powrocie do procedowania trasy linii w przebiegu zawartym w PZPWM. Zapowiedziano wówczas, że inwestycja może być realizowana na podstawie przepisów przyjętej w tym czasie ustawy z dnia 24 lipca 2015 r. o przygotowaniu i realizacji strategicznych inwestycji w zakresie sieci przesyłowych, zwanej specustawą przesyłową. Decyzja ta nie została zaakceptowana przez uczestników konfliktu związanych terytorialnie z trasą z PZPWM. Protesty z blokadami dróg trwały nadal, a na osiągnięcie porozumienia w drodze negocjacji nie było już szans. Sytuacja ta zaowocowała 7 listopada 2016 r. decyzją o rozwiązaniu umowy na budowę linii, zawartej w 2014 r. przez PSE S.A. z wykonawcą (konsorcjum ZUE S.A. i Dalekovod Polska S.A.). Uznano, że na skutek okoliczności niezależnych od stron, realizacja tej umowy okazała się niemożliwa. 


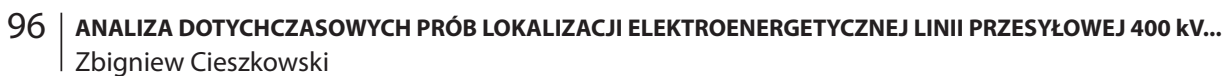

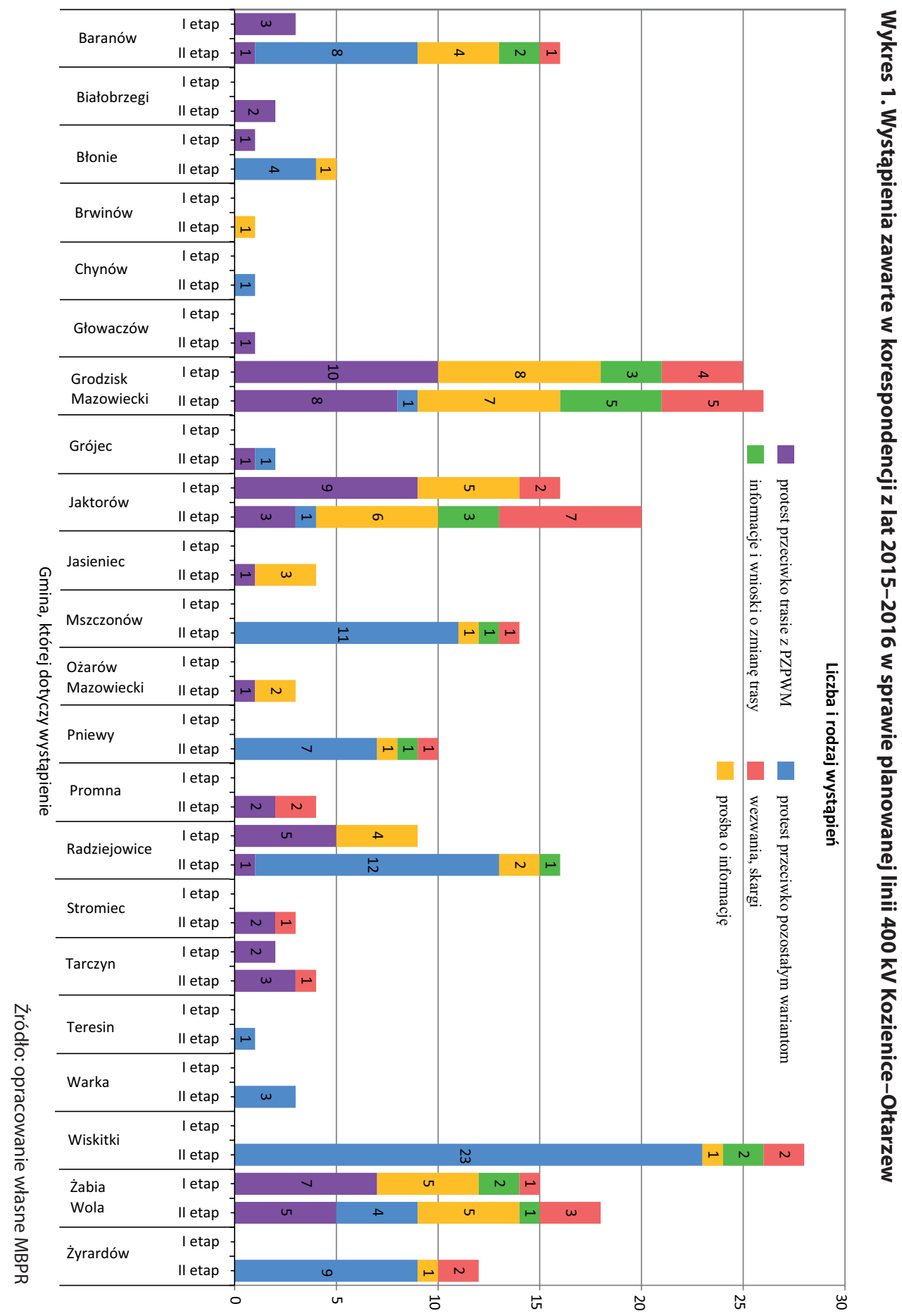


W okresie od 20 lipca 2015 r. do końca 2016 r., czyli na etapie poszukiwania alternatywnych lokalizacji linii $400 \mathrm{kV}$ Kozienice-Ołtarzew, osoby prywatne, stowarzyszenia, organizacje społeczne, media, samorządy lokalne, radni Sejmiku WM, posłowie na Sejm RP i prawnicy kierowali różnego rodzaju pisma do: Marszałka WM, Sejmiku WM, Wojewody Mazowieckiego, PSE S.A. i API, Ministra Energii, Rządu RP, Wojewódzkiego Sądu Administracyjnego, Mazowieckiego Biura Planowania Regionalnego (MBPR). W tym okresie władze województwa otrzymały łącznie 135 pism (kierowanych bezpośrednio lub przekazywanych do wiadomości), z których znaczna część dotyczyła merytorycznie więcej niż jednej gminy. Około połowa pism obejmowała protesty przeciwko różnym wariantom linii, głównie innym niż wariant z PZPWM (wykres 1, mapa 3). W pozostałych pismach były:

- prośby o udzielenie informacji w zakresie procedury wprowadzenia linii do PZPWM, konsultacji społecznych, stanowisk rad gmin w procesie opiniowania projektu planu, wezwania do usunięcia naruszeń prawa, skargi do WSA,

- informacje przekazywane przez autorów wystąpień i wnioski o zmianę trasy.

Nowym zjawiskiem w fali protestów przeciwko linii 400 kV Kozienice-Ołtarzew, było przyjmowanie przez rady gmin i rady powiatów uchwał lub stanowisk wyrażających sprzeciw wobec lokalizacji przedmiotowej inwestycji na ich terenie - łącznie do końca $2016 \mathrm{r}$. takie uchwały lub stanowiska podjęło 6 gmin (w kolejności chronologicznej: Baranów, Żyrardów, Wiskitki, Chynów, Tarczyn, Grójec) oraz 3 powiaty (białobrzeski, piaseczyński i grodziski). Rada Powiatu Grodziskiego przyjęła przedmiotowe stanowisko 3 dni po podjęciu przez Sejmik Województwa Mazowieckiego w dniu 21 listopada 2016 r. uchwały w sprawie przystąpienia do sporządzenia kompleksowej zmiany PZPWM (jednocześnie została uchylona uchwała z 27 lipca 2015 r., o której mowa w części 2., w sprawie zmiany planu tylko w zakresie linii Kozienice-Ołtarzew).

Analiza korespondencji prowadzonej na omówionym wyżej etapie wykazała, że protesty dotyczyły 22 z 30 gmin położonych na trasach pięciu wariantów linii, w tym 15 z 16 gmin na trasie uwzględnionej w planie województwa, która w pierwszym etapie korespondencji budziła emocje w 7 gminach (teraz protesty nie objęły jedynie gminy Kozienice). Najsilniejszy sprzeciw dotyczył gminy Wiskitki, przez której teren przebiegają 2 warianty linii wykorzystujące korytarz drogi krajowej nr 50, bardzo aktywne były nadal podmioty z gminy Grodzisk Mazowiecki i gmin bezpośrednio z nią sąsiadujących.

\section{Podsumowanie}

W podsumowaniu należy stwierdzić, że w dotychczasowym procesie planowania lokalizacji linii $400 \mathrm{kV}$ Kozienice-Ołtarzew, inwestor popełnił wiele rażących błędów, które zaowocowały niepowodzeniem przy próbie ustalenia jej dokładnej trasy w dokumentach planistycznych gmin. Pierwszym był brak konsekwencji w wykorzystaniu efektów konsultacji z samorządami gminnymi w latach 2006-2007 na etapie sporządzania studium wykonalności przedmiotowej linii (o których mowa w części 2.). Na tamtym etapie dialogu inwestora z gminami istniała bardzo duża szansa na wprowadzenie inwestycji do 
studiów uwarunkowań i kierunków zagospodarowania przestrzennego, a później planów miejscowych. Bardzo ogólne zapisy ówczesnego PZPWM z 2004 r. dotyczące zasad rozwoju elektroenergetycznego systemu przesyłowego (o których mowa w części 1.) umożliwiały wprowadzanie sieci przesyłowych do dokumentów planistycznych gmin.

Poważny błąd popełniły także samorządy gminne, które nie dochowały należytej staranności w procesie konsultowania projektu nowego Planu Zagospodarowania Przestrzennego Województwa Mazowieckiego (opracowywanego w latach 2011-2014) ze społecznościami lokalnymi. Brak informacji o planowanej linii był najważniejszym zarzutem protestujących przeciwko inwestycji, a należy zwrócić uwagę, że w trakcie organizowanych przez samorząd Województwa Mazowieckiego konferencji konsultacyjnych, a także po pisemnych wystąpieniach o opinie, ówczesne władze gminne nie zgłosiły sprzeciwu wobec przedmiotowej inwestycji (z wyjątkiem gminy Grodzisk Mazowiecki - w odniesieniu do niewielkiego fragmentu linii w południowej części gminy).

Kolejnymi, brzemiennymi w skutkach działaniami na rzecz ustalenia lokalizacji linii Kozienice-Ołtarzew, były rozpoczęte przez jej wykonawcę w pierwszej połowie $2015 \mathrm{r}$. wstępne prace projektowe $\mathrm{w}$ terenie, które spowodowały pierwsza, jeszcze stosunkowo nieliczną liczbę wystąpień pisemnych przeciwko inwestycji. Brak odpowiedniej reakcji inwestora na te protesty, a następnie dalsze wydarzenia i sprzeczne ze sobą decyzje (o których mowa w części 3.) przesądziły o niepowodzeniu tego przedsięwzięcia.

O tym, że próby lokalizacji linii $400 \mathrm{kV}$ Kozienice-Ołtarzew będą jeszcze kontynuowane $\mathrm{w}$ przyszłości świadczą informacje przekazane władzom gmin, leżących na trasie projektowanej linii, podczas spotkania zorganizowanego przez PSE S.A. w dniu 22 lutego 2017 r. Przyjęto nowy model realizacji inwestycji, który ma być „zrównoważony $i$ optymalny z punktu widzenia społeczności lokalnych". Podczas spotkania przedstawiciele inwestora poinformowali, że "obecnie trwaja wnikliwe prace analityczne dotyczace wykonalności inwestycji. Szczegótowym analizom $w$ obszarze technicznym $i$ administracyjnym poddane zostana wszystkie możliwe korytarze tras. Publiczne zaprezentowanie wyników tych prac planowane jest w połowie 2018 roku. Następnie będa one przedmiotem konsultacji społecznych"1.

Należy podkreślić, że z punktu widzenia systemowego, linia $400 \mathrm{kV}$ KozieniceOłtarzew uznawana jest przez PSE S.A. za niezbędny element domykający warszawski pierścień elektroenergetyczny, w którym znajduje się rozbudowywana elektrownia systemowa Kozienice. Linia ta pozostała w wykazie inwestycji strategicznych w specustawie przesyłowej, mimo nowelizacji tej ustawy w lutym 2017 r., polegającej m.in. na uwzględnieniu budowy dwóch linii 400 kV zlokalizowanych na wschód od Warszawy, które umożliwią wyprowadzenie mocy z elektrowni Kozienice w kierunku północnym.

\footnotetext{
${ }^{1}$ Informacja internetowa portalu e-Energetyka z dnia 28.02.2017 r. pt. Spotkanie w sprawie połaczenia Elektrowni Kozienice ze stacja Ottarzew na podstawie informacji PSE S.A.
} 
Mapa 3. Wystąpienia zawarte w korespondencji z lat 2015-2016 w sprawie planowanej linii 400 kV Kozienice-Ołtarzew

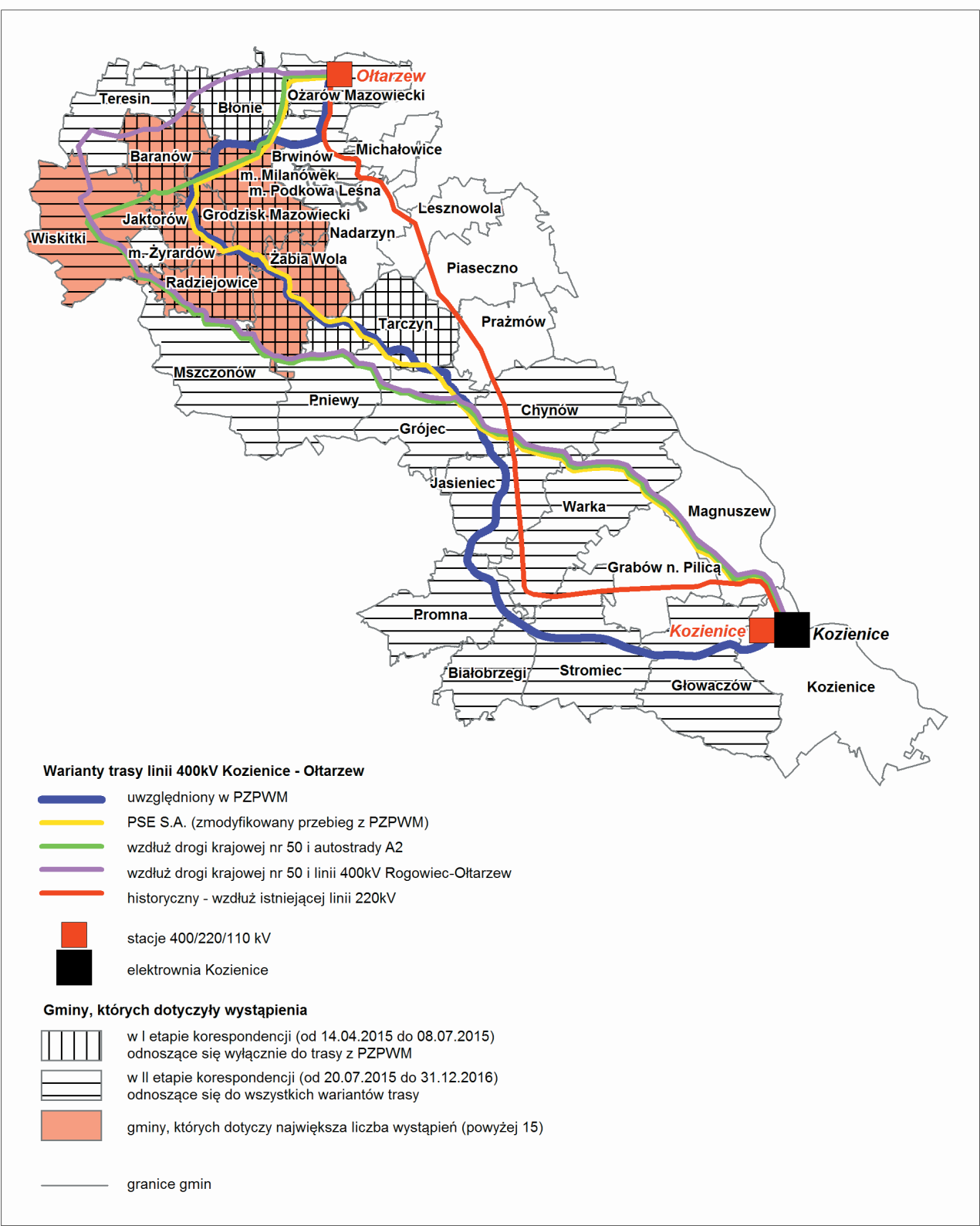

Źródło: opracowanie własne MBPR 


\section{Słownik skrótów}

A2 - autostrada w ciągu drogi krajowej nr 2

API - Agencja Promocji Inwestycji Spółka z o.o.

BPRW - Biuro Projektów Rozwoju Warszawy

DK 50 - droga krajowa nr 50

EC - elektrociepłownia

KPZK - Koncepcja Przestrzennego Zagospodarowania Kraju 2030

MBPR - Mazowieckie Biuro Planowania Regionalnego

PSE S.A. - Polskie Sieci Elektroenergetyczne S.A.

PZPWM - Plan Zagospodarowania Przestrzennego Województwa Mazowieckiego

RP - Rzeczpospolita Polska

Specustawa przesyłowa - Ustawa z dnia 24 lipca 2015 r. o przygotowaniu i realizacji strategicz-

nych inwestycji w zakresie sieci przesyłowych

WM - Województwo Mazowieckie

WSA - Wojewódzki Sąd Administracyjny

WWE - Warszawski Węzeł Elektroenergetyczny

ZUE S.A. - Zakłady Usług Energetycznych i Komunikacyjnych

\section{Akty prawne i dokumenty}

Koncepcja Przestrzennego Zagospodarowania Kraju 2030, Uchwała nr 239 Rady Ministrów z dnia 13 grudnia 2011 r. w sprawie przyjęcia Koncepcji Przestrzennego Zagospodarowania Kraju 2030, M.P. z 2012 r., poz. 252.

Plan Zagospodarowania Przestrzennego Województwa Mazowieckiego, Uchwała nr 65/04 Sejmiku Województwa Mazowieckiego z dnia 7 czerwca 2004 r., Dz.Urz.Woj.Maz. z 2004 r., nr 217, poz. 5811.

Plan Zagospodarowania Przestrzennego Województwa Mazowieckiego, Uchwała nr 180/14 Sejmiku Województwa Mazowieckiego z dnia 7 lipca 2014 r., Dz.Urz.Woj.Maz. z 2014 r., poz. 6868.

Ustawa z dnia 7 lipca 1994 r. o zagospodarowaniu przestrzennym, Dz.U. z 1994 r., nr 89, poz. 415.

Ustawa z dnia 27 marca 2003 r. o planowaniu i zagospodarowaniu przestrzennym, Dz.U. z 2012 r., poz. 647 , z późn. zm.

Ustawa z dnia 24 lipca 2015 r. o przygotowaniu $i$ realizacji strategicznych inwestycji w zakresie sieci przesyłowych, Dz.U. z 2015 r., poz. 1265 z późn. zm. 


\section{Bibliografia}

Bezpieczeństwo elektroenergetyczne Aglomeracji Warszawskiej w aspekcie budowy południowego pótpierścienia 400 kV, 2011, Raport z debaty organizowanej przez Biuro Infrastruktury Miasta Stołecznego Warszawy, Warszawa.

Budowa linii elektroenergetycznej 400 kV Kozienice-Ottarzew, 2015, PSE S.A., KonstancinJeziorna.

Gochnio B., Sprawozdania ze spotkań Grupy Roboczej w sprawie lokalizacji linii elektroenergetycznej 400 kV Kozienice-Ołtarzew (22 marca 2016 r., 6 kwietnia 2016 r., 16 maja 2016 r.), materiał niepublikowany, przechowywany w archiwum MBPR.

Informacja dla Marszałka WM nt. podjętych działań związanych z projektowaniem lokalizacji linii 400 kV Kozienice-Ołtarzew, sporządzona w maju 2016 r. przez MBPR, Warszawa.

Informacja dla Zarządu Województwa Mazowieckiego w sprawie linii elektroenergetycznej 400 kV Kozienice-Ołtarzew, sporządzona 29 września 2016 r. przez MBPR, Warszawa.

Komunikat Centrum Informacji o Rynku Energii z dnia 7 listopada 2016 r. dotyczący rozwiązania kontraktu na budowę linii 400 kV relacji Kozienice-Ołtarzew.

Koncepcja generalna rozwoju systemu elektroenergetycznego dla województwa stołecznego warszawskiego, 1977, Biuro Planowania Rozwoju Warszawy, Warszawa.

Korespondencja w sprawie linii 400 kV Kozienice-Ołtarzew z lat 2015-2016, skierowana do samorządu województwa (bezpośrednio lub przekazana do wiadomości).

Molęda S., 2005, Rozwój elektroenergetyki na terenie Warszawy, SEP Oddział Warszawski, Warszawa.

Odpowiedź Ministra Energii nr DE/1959/15 z dnia 7 stycznia 2016 r. na oświadczenie złożone przez Marszałka Senatu podczas 4. Posiedzenia Senatu RP w sprawie planowanej budowy linii wysokiego napięcia na terenie gminy Pniewy w powiecie grójeckim.

Odpowiedź sekretarza stanu w Ministerstwie Gospodarki - z upoważnienia ministra - na interpelację nr 13429 w sprawie warunków budowania linii energetycznych w Polsce.

Odpowiedź Sekretarza Stanu w Ministerstwie Gospodarki udzielona w dniu 28 sierpnia 2015 r. na interpelacje poselską nr 33504, w sprawie budowy linii przesyłowej elektroenergetycznej o mocy 400 kV Kozienice-Ołtarzew.

Opinia prawna radcy prawnego Janusza Siekańskiego, przygotowana na zlecenie PSE S.A., dotycząca opinii prawnej związanej z ustawą o przygotowaniu i realizacji strategicznych inwestycji w zakresie sieci przesyłowych, 19 listopada 2015, Warszawa. 
Opinia prawna radcy prawnego Rafała Marchewki dot. problemów prawnych związanych z lokalizacją Linii elektroenergetycznej najwyższych napięć 400 kV Kozienice-Ołtarzew na podstawie przepisów ustawy z dnia 27 marca 2003 r. o planowaniu $i$ zagospodarowaniu przestrzennym oraz przepisy ustawy $z$ dnia 24 lipca 2015 r. o przygotowaniu $i$ realizacji strategicznych inwestycji w zakresie sieci przesyłowych.

Opinia prawna z dnia 6 lipca 2016 r. dotyczącą problemów prawnych związanych z lokalizacją linii 400 kV Kozienice-Ołtarzew sporządzona przez Departament Organizacji UMWM w Warszawie.

Partycypacyjna Analiza Wielokryterialna - Wyniki dla projektu linii elektroenergetycznej KOZ-OLT, prezentacja.

Plan rozwoju w zakresie zaspokojenia obecnego i przyszłego zapotrzebowania na energię elektryczna na lata 2010-2025, 2009, PSE S.A., Konstancin-Jeziorna.

Plan rozwoju w zakresie zaspokojenia obecnego i przyszłego zapotrzebowania na energię elektryczna na lata 2016-2025, 2015, PSE S.A., Konstancin-Jeziorna.

Poprawa bezpieczeństwa zasilania aglomeracji warszawskiej przez rozbudowę linii najwyższych napięć od strony południowej, X Międzynarodowa Konferencja: „Nowoczesne urządzenia zasilające w energetyce", 14-16 marca 2007, Zakopane.

Południowy pótpierścień 400 kV jako przesłanka do rozwoju aglomeracji warszawskiej i województwa mazowieckiego, prezentacja, 18 marca 2011, MBPR , Warszawa.

Prognoza oddziatywania na środowisko Miejscowego planu zagospodarowania przestrzennego dla rejonu pasa technologicznego linii wysokiego napięcia 400 kV relacji Miłosna-Siedlce Ujrzanów przebiegającej przez teren miasta Sulejówek, 2014, Urząd Miasta Sulejówek, Warszawa.

Raport o oddziaływaniu na środowisko stacji elektroenergetycznej 400/220/110 kV Ottarzew wraz z wprowadzeniami liniowymi na terenie gminy Ożarów Mazowiecki w obrębie Pogroszew, 2010, EKOKONSULT Biuro Projektowo-doradcze, Gdańsk-Wrocław.

Raport Zrównoważonego Rozwoju Polskich Sieci Elektroenergetycznych S.A. Inwestujemy w rozwój sieci, 2014, PSE.

Rozbudowa Warszawskiego Węzła Elektroenergetycznego, 2007, PSE-Operator S.A., Warszawa.

Rys historyczny prac koncepcyjnych zwiazanych z budowa pierścienia 400 kV wokót Warszawy, debata: „Bezpieczeństwo elektroenergetyczne aglomeracji warszawskiej w aspekcie budowy południowego półpierścienia 400 kV", 18 marca 2011, Warszawa.

Stan aktualności studiów uwarunkowań i kierunków zagospodarowania przestrzennego gmin w województwie mazowieckim, 2015, MBPR, Warszawa. 
Stenogramy ze spotkań Forum Dialogu - w sprawie przebiegu linii elektroenergetycznej 400 kV Kozienice-Ołtarzew (3 września 2015 r., 17 września 2015 r., 18 lutego 2016 r.).

Studium wykonalności budowy linii 400 kV Kozienice-Ottarzew/ Sochaczew, 2007, Energoprojekt, Kraków.

Wybrane zagadnienia budowy i eksploatacji sieci przesyłowych najwyższych napięć, W. Kamrat (Politechnika Gdańska) i T. Szczepański (PSE Północ), plik PDF.

Studia uwarunkowań i kierunków zagospodarowania przestrzennego gmin:

Baranów, Białobrzegi, Brwinów, Chynów, Głowaczów, Grodzisk Mazowiecki, Grójec, Jaktorów, Jasieniec, Kozienice, Ożarów Mazowiecki, Promna, Radziejowice, Stromiec, Tarczyn, Żabia Wola

\title{
An analysis of attempts at establishing the route of the Kozienice-Ołtarzew $400 \mathrm{kV}$ electric transmission line
}

\begin{abstract}
The aim of this article is to present the conditions of and actions towards establishing the route of the high-voltage Kozienice-Ołtarzew electric transmission line, a significant element of the high-voltage ring around Warsaw which contributes to the reliability of power supply in the Warsaw metropolis and western Mazovia. The power transmission system's operational safety is the responsibility of Polskie Sieci Elektroenergetyczne S.A. (Polish Power Network - PSE S.A.), the operator of the system in Poland. The demand for electricity in Mazovia is constantly rising, especially in the Warsaw metropolis. In effect, the national power transmission grid requires development. The article presents the historical plans for the development of the transmission system which supplies Warsaw with electricity and the actions undertaken in order to introduce the $400 \mathrm{kV}$ Kozienice-Ołtarzew line to local (municipal) spatial planning documents which led to protests against the investment in 2015. Inhabitants, social groups and local governments expressed their discontent in letters addressed, inter alia, to the investor (PSE S.A.), government institutions and the Regional Government of Mazovia. The regional government was not passive and took part in the dialogue as a mediator between the national government and the local governments/social groups. In September 2015, at the initiative of the Regional Assembly of Mazovia, a Dialogue Forum was set up. The forum's participants included representatives of the investor, the national government, municipalities and local inhabitants. The forum's goal was to identify a compromise concerning the route of the Kozienice-Ołtarzew $400 \mathrm{kV}$ line which could be included in the modified Spatial Development Plan of the Mazovia Region. The article presents the versions analyzed and the method of choosing the optimal route, which eventually was not used due to the large scale of protests. At the beginning of 2017, PSE S.A. adopted a new approach to the investment and commenced analytical works intended to identify the line's route. The investor plans to publicly presents the results of these works in mid-2018 and subject them to public consultations.
\end{abstract}

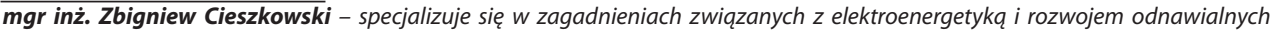
źródeł energii, pracownik Oddziału Terenowego w Siedlcach Mazowieckiego Biura Planowania Regionalnego w Warszawie, kontakt: Oddział Terenowy w Siedlcach Mazowieckiego Biura Planowania Regionalnego w Warszawie, ul. Pułaskiego 19/21, 08-110 Siedlce, e-mail:zcieszkowski@mbpr.pl
} 